\title{
Incidence of Gastrointestinal Parasitism in Cattle in Gazipur, Bangladesh
}

\author{
Fahima Khatun ${ }^{1}$, Abdullah-Al-Maruf ${ }^{2}$, Md. Mizanur Rahman ${ }^{2}$, Afroja Yasmin ${ }^{1}$, Mohammad Ali Zinnah ${ }^{3}$, \\ Md. Aminul Islam ${ }^{4}$ and Mohammad Shah Alam ${ }^{5 *}$
}

${ }^{1}$ Department of Pathobiology, Bangabandhu Sheikh Mujibur Rahman Agricultural University, Gazipur, Bangladesh; ${ }^{2}$ Department of Livestock Service, Bangladesh; ${ }^{3}$ Department of Microbiology and Hygiene, Bangabandhu Sheikh Mujibur Rahman Agricultural University, Gazipur, Bangladesh; ${ }^{4}$ Department of Medicine, Bangabandhu Sheikh Mujibur Rahman Agricultural University, Gazipur, Bangladesh; ${ }^{5}$ Department of Anatomy and Histology, Bangabandhu Sheikh Mujibur Rahman Agricultural University, Gazipur, Bangladesh.

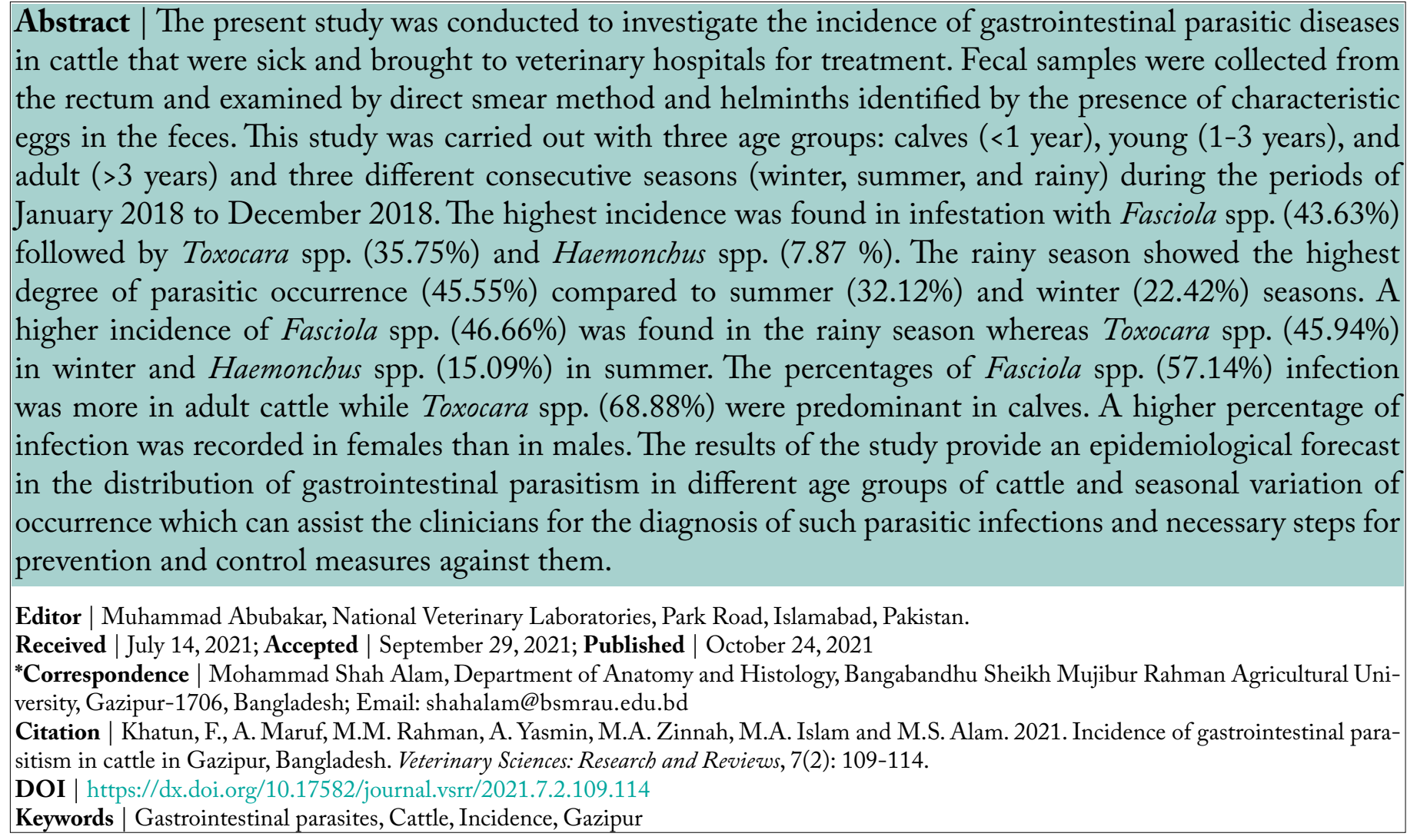

\section{Introduction}

$\mathrm{P}$ arasitic infection is a major impediment to health and livestock production in tropical and subtropical countries including Bangladesh (Islam et al., 2020; Kakar and Kakarsulemankhel, 2008). All age groups of cattle are infected by a diverse set of gastrointestinal parasites (Alim et al., 2012; Islam et al., 2020). Although these infections are always not injurious with high mortality in cattle, their effects are commonly characterized by retarded growth, low productivity and increased susceptibility of animals to other infections (Radostits et al., 2006). These parasitic infestations are associated with overall 
economic losses in the livestock industry (Bary et al., 2018; Rinaldi et al., 2011). Despite having significant losses from gastrointestinal parasitic infections, the problems are often ignored because the majority of the infected animals show subclinical or chronic infections (Raza et al., 2010).

Among the factors affecting the health and productivity of cattle, gastrointestinal parasitism is one of the leading obstacles in the cattle industry in Bangladesh (Admasu and Nurlign, 2014). Among the gastrointestinal parasites; coccidian, ascarid, strongyle, Setaria, and amphistomes were mostly in tropical and temperate countries like India, Bangladesh, South Africa, Sri Lanka, Italy, and Mongolia, with a prevalence rate ranging from 20 to 96\% (Gwaze et al., 2009; Hassan et al., 2011; Lone et al., 2011; Sharma et al., 2009; Sharma and Busang, 2014). Various epidemiological studies of gastrointestinal parasites in cattle have been conducted in different parts of Bangladesh (Ahmed et al., 2015; Alim et al., 2012; Sardar et al., 2006), and has been shown that gastrointestinal parasitic infestation varies depending on the prevailing climatic conditions and farm management practices. Therefore, it is important to map out the parasitic infestation accurately in different agro-climatic zones for taking appropriate control measures. As far as we are aware of there is very scanty information on the seasonal prevalence of gastrointestinal parasitic infections in cattle in Bangladesh. The prevalence of parasitic infection depends on ecology, geographical and climatic condition prevailing in Bangladesh (Hossain et al., 2004). Since Gazipur is the central place of Bangladesh, so its geo-climatic conditions represent the whole of Bangladesh. In addition, this district has a rich source of cattle, so, it is the time demand, to conduct a thorough study regarding the occurrences of gastrointestinal parasitic diseases and their co-relation with seasonal variance. Therefore, the present study has been undertaken to investigate the prevalence of gastrointestinal parasitic infections in cattle presented at upazila veterinary hospital of Gazipur with various alignments and the specific objective was to determine their incidence and evolving the strategic and tactical methods of control.

\section{Materials and Methods}

\section{Study period and area}

The fecal samples were collected from cattle in the upazila veterinary hospital, Gazipur from January 2018 to December 2018.

\section{Study questionnaire}

To record the information of the animal, a questionnaire was developed where owner name and address, patient age and sex, and prescription such as anthelmintic treatment, ration formulation are mentioned. Although the questionnaire was written in English, it was translated to bangle (our native) language during a face-to-face interview with the owner of the patient hen the as well as samples collection.

\section{Sample collection}

The clinical samples of cattle were collected after examining the clinical status of the animal by the veterinary surgeon at the veterinary hospital. Fecal samples were collected from the rectum of the animals having digestive disturbances. The samples were then examined immediately.

\section{Sample examination}

Sample examination was performed as previously described by (Siddiki et al., 2010). Briefly, two or three thin smears were prepared with the feces for each cattle and then examined under the microscope with low power objectives (10X). Positive cases were diagnosed based on the characteristic morphological feature of eggs of helminth parasites (Soulsby, 1982). The results of fecal sample examination were then recorded according to age, seasons, and sex of animals.

\section{Calculation}

The collected data were entered and managed in an MS Excel worksheet. The proportion of different parasitism was expressed as a percentage by dividing the total number of cattle positive to a specific parasitic egg to the total no of cattle examined.

\section{Results and Discussion}

The data were recorded based on the season of the year and the age of the animals. The year was arbitrarily divided into Summer (March to May), Rainy (June to October), and Winter (November to February) seasons, and the animals were categorized into 3 age groups: calves ( $<1$ year), young ( $1-3$ year) and adult (>3 years).

Table 1 shows the overall prevalence of gastrointestinal 
parasitic diseases in cattle in Gazipur Sadar. The prevalence of Fasciola spp. was (43.63\%) followed by Toxocara spp. (35.75\%) and Haemonchus spp. (7.87\%). The highest incidence of parasites was observed in the rainy season (45.55\%) followed by summer (32.12\%) and winter $(22.42 \%)$ which is shown in Table 2 . These findings are well consistent with the observations of (Alim et al., 2012) and (Hassan et al., 2018). Lacking optimum moisture and temperature for the development of larvae in the pasture during the hot and cold season lowers and lowest the prevalence during summer and winter respectively. In the rainy season, the abundant rainfall and availability of an intermediate host of trematode favor the migration and development of the infective stage in snails. Here, it was shown that, the highest prevalence of Fasciola spp. (46.66\%) in rainy season were found in line with the reports of (Ghosh et al., 2016; Radostits et al., 2006). Infection with Haemonchus spp. were predominant in the summer season agreed with the observation of (Pfukenyi et al., 2007) and (Urquhart et al., 1996). They mentioned relatively high temperature and humidity are suitable for the larval development and survival in the pasture of such parasites. On the other side, the highest prevalence of Toxocara spp. (45.94\%) were found in the winter season which is negatively correlated with the other studies (Alim et al., 2012).

Table 3 shows the prevalence of gastrointestinal parasitic diseases in cattle in three different age groups. The prevalence of parasitic infection in adult cattle (over 3 years) was higher which might be due to longer periods of grazing times (Sardar et al.,
2006). In addition, some predisposing factors like lactation, pregnancy, nutritional deficiency might be accounted for higher infection in adult cattle (Radostits et al., 2006). The calves under one-yearold had a significantly higher prevalence of Toxocara spp. (68.88\%) infection than young and adult. This study strongly supported the findings of (Avcioğlu and Balkaya, 2011) who reported higher infection at $0-12$ months of age group. The high prevalence of this parasitic infection in calves might be related to prenatal infection through the transfer of third larval stage (L3) and poor hygienic conditions during the post-natal period (Dorny et al., 2015; Roberts et al., 1990). Regarding Fasciola spp., the prevalence of infection found in adult cattle agrees with those reported by (Sardar et al., 2006; Alim et al., 2012) conducted in Bangladesh who reported that Fasciola spp. were highest in the age group more than 36 months. Infection with Bunostomum spp. (8.00\%) were higher in the young group (1-3 years) possibly due to sudden exposure to grazing land containing a huge number of larvae of parasites.

\begin{tabular}{|c|c|c|c|}
\hline S. No. & Parasite species & No of infection & Prevalence \\
\hline 1 & Fasciola spp. & 72 & $43.63 \%$ \\
\hline 2 & Toxocara spp. & 59 & $35.75 \%$ \\
\hline 3 & Strongyloidosis spp. & 7 & $4.24 \%$ \\
\hline 4 & Bunostomum spp. & 6 & $3.63 \%$ \\
\hline 5 & Hemonchus spp. & 13 & $7.87 \%$ \\
\hline \multirow[t]{2}{*}{6} & Paramphostomum spp. & 8 & $4.84 \%$ \\
\hline & & Total & 165 \\
\hline
\end{tabular}

Table 2: Prevalenceloccurrence of gastrointestinal parasitic infections in different seasons.

\begin{tabular}{|c|c|c|c|c|c|c|c|c|}
\hline \multirow[t]{2}{*}{ Season } & \multicolumn{6}{|c|}{ Different parasitic load } & \multirow[t]{2}{*}{ Total } & \multirow{2}{*}{$\begin{array}{l}\% \text { infes- } \\
\text { tation }\end{array}$} \\
\hline & Fasciola spp. & Toxocara spp. & $\begin{array}{l}\text { Strongyloidosis } \\
\text { spp. }\end{array}$ & $\begin{array}{l}\text { Bunostomum } \\
\text { spp. }\end{array}$ & $\begin{array}{l}\text { Haemonchus } \\
\text { spp. }\end{array}$ & $\begin{array}{l}\text { Paramphisto- } \\
\text { mum spp. }\end{array}$ & & \\
\hline Winter & $15(40.54 \%)$ & $17(45.94 \%)$ & $1(2.70 \%)$ & $2(5.40 \%)$ & $2(5.54 \%)$ & - & 37 & 22.42 \\
\hline Rainy season & $35(46.66 \%)$ & $25(33.33 \%)$ & $4(5.33 \%)$ & $2(2.66 \%)$ & $3(4.00 \%)$ & $6(8.00 \%)$ & 75 & 45.55 \\
\hline Summer & $22(41.50 \%)$ & $17(32.07 \%)$ & $2(3.77)$ & $2(3.77 \%)$ & $8(15.09 \%)$ & $2(5.40 \%)$ & 53 & 32.12 \\
\hline Total & & & & & & & 165 & \\
\hline
\end{tabular}

Table 3: Prevalenceloccurrence of gastrointestinal parasitic infections in different age groups.

\begin{tabular}{|c|c|c|c|c|c|c|c|c|}
\hline \multirow[t]{2}{*}{ Age group } & \multicolumn{6}{|c|}{ Different parasitic load } & \multirow[t]{2}{*}{ Total } & \multirow{2}{*}{$\begin{array}{l}\% \\
\text { infes- } \\
\text { tation }\end{array}$} \\
\hline & Fasciola spp. & $\begin{array}{l}\text { Toxocara } \\
\text { spp. }\end{array}$ & $\begin{array}{l}\text { Strongyloidosis } \\
\text { spp. }\end{array}$ & $\begin{array}{l}\text { Bunostomum } \\
\text { spp. }\end{array}$ & $\begin{array}{l}\text { Haemonchus } \\
\text { spp. }\end{array}$ & $\begin{array}{l}\text { Paramphi } \\
\text { stomum spp. }\end{array}$ & & \\
\hline Calf $(<1$ Year $)$ & $9(20.00 \%)$ & $31(68.88 \%)$ & $1(2.22 \%)$ & $2(4.44 \%)$ & $1(2.22 \%)$ & - & 45 & 27.27 \\
\hline Young (1-3 Year) & $28(56.00 \%)$ & $12(24.00 \%)$ & $3(6.00 \%)$ & $4(8.00 \%)$ & $1(2.00 \%)$ & $2(4.00 \%)$ & 50 & 30.30 \\
\hline Adult $(>3)$ & $40(57.14 \%)$ & $13(18.57 \%)$ & $4(5.71 \%)$ & $3(4.28 \%)$ & $7(10.00 \%)$ & $3(4.28 \%)$ & 70 & 42.42 \\
\hline Total & & & & & & & 165 & \\
\hline
\end{tabular}


Table 4: Prevalenceloccurrence of parasitic diseases in different sex groups.

\begin{tabular}{|c|c|c|c|c|c|c|c|c|}
\hline \multirow[t]{2}{*}{ Sex group } & \multicolumn{6}{|c|}{ Different parasitic load } & \multirow[t]{2}{*}{ Total } & \multirow{2}{*}{$\begin{array}{l}\% \text { infesta- } \\
\text { tion }\end{array}$} \\
\hline & Fasciola spp. & Toxocara spp. & $\begin{array}{l}\text { Strongyloidosis } \\
\text { spp. }\end{array}$ & $\begin{array}{l}\text { Bunostomum } \\
\text { spp. }\end{array}$ & $\begin{array}{l}\text { Haemonchus } \\
\text { spp. }\end{array}$ & $\begin{array}{l}\text { Paramphi } \\
\text { Stomum spp. }\end{array}$ & & \\
\hline Female & $80(64.00 \%)$ & $20(16.00 \%)$ & $10(8.00 \%)$ & $5(4.00 \%)$ & $7(5.60 \%)$ & $3(2.40 \%)$ & 125 & $75.75 \%$ \\
\hline Male & $20(50.00 \%)$ & $8(20.00 \%)$ & $4(10.00 \%)$ & $6(15.00 \%)$ & $2(5.00 \%)$ & - & 40 & $24.24 \%$ \\
\hline Total & & & & & & & 165 & \\
\hline
\end{tabular}

Overall, the sex-specific prevalence of gastrointestinal parasitic infestation was more predominant in female than male cattle (Table 4). These findings are in agreement with the other study reported by (Raza et al., 2007, 2010). Strongylodosis spp. and Bunostomum spp. infection was found higher in a male animal. The changing of occurrence of such parasitic infections in male and female animals might be due to the alteration in sample size (Bachal et al., 2002), lowered resistance of female animals or temporary loss of acquired immunity near parturition (Garcia et al., 2007), and insufficient feed supply against their higher needs (Hansen and Perry, 1994; Raza et al., 2010).

\section{Conclusions and Recommendations}

It can be concluded from the current study that the occurrence of gastrointestinal helminth parasites was highest in rainy season followed by summer and winter. In the species wise comparison, Fasciola spp. was highly prevalent while the occurrences of Bunostomum spp. were the lowest. Age specific prevalence of gastrointestinal helminthes Fasciola spp. were found more in adult cattle Toxocara spp in calf less than one year. Higher percentages of helminthes infections found in female cattle as compared to male. However, this study provides some epidemiological ideas in the occurrence of such diseases in cattle and aware the farmers to take necessary preventive and control measures against them.

\section{Novelty Statement}

As far as we are aware that this is the first report of gastrointestinal parasitism in large animal in Gazipur district, Bangladesh. The study provide an epidemiological forecast in the distribution of gastrointestinal parasitism in different age groups of cattle and seasonal variation of occurrence.

\section{Author's Contribution}

FK and MSA conceived and designed the study and wrote the manuscript. AM and MMR performed the experiments. AY, MAZ and MAI contributed to review the manuscript. MSA supervised and approved it for final publishing.

\section{Conflict of interest}

The authors have declared no conflict of interest.

\section{References}

Admasu, P., and Nurlign, L., 2014. Prevalence of gastrointestinal parasites of small ruminants in Kuarit District, North West Ethiopia. Afr. J. Bas. Appl. Sci., 6: 125-130.

Ahmed, R., Biswas, P.K., Barua, M., Alim, M.A., Islam, K., and Islam, M.Z., 2015. Prevalence of gastrointestinal parasitism of cattle in Banskhali upazilla, Chittagong, Bangladesh. J. Adv. Vet. Anim. Res., 2: 484-488. https://doi. org/10.5455/javar.2015.b113

Alim, M., Das, S., Roy, K., Sikder, S., Mohiuddin, M.M., and Hossain, M., 2012. Prevalence of gastrointestinal parasites in cattle of Chittagong division, Bangladesh. Wayamba J. Anim. Sci., 4: 1-8.

Avcioğlu, H., and Balkaya, I., 2011. Prevalence of Toxocara vitulorum in calves in Erzurum, Turkey. Kafkas Univ. Vet. Fak. Derg., 17: 345347.

Bachal, B., Sharif, P., Rahamatullah, R., and Aijaz, H., 2002. Prevalence of gastro-intestinal helminths in Buffalo calves. J. Biol. Sci., 2: 4345. https://doi.org/10.3923/jbs.2002.43.45

Bary, M., Ali, M., Chowdhury, S., Mannan, A., Nur e Azam, M., Moula, M., Bhuiyan, Z., Shaon, M., and Hossain, M., 2018. Prevalence and molecular identification of haemoprotozoan diseases of cattle in Bangladesh. Adv. Anim. Vet. Sci., 6: 176-182. https://doi.org/10.17582/ journal.aavs/2018/6.4.176.182

Dorny, P., Devleesschauwer, B., Stoliaroff, V., Sothy, M., Chea, R., Chea, B., Sourloing, H., Samuth, 
S., Kong, S., and Nguong, K., 2015. Prevalence and associated risk factors of Toxocara vitulorum infections in buffalo and cattle calves in three provinces of central Cambodia. Korean J. Parasitol., 53: 197-200. https://doi. org/10.3347/kjp.2015.53.2.197

Garcia, J.A., Rodriguez-Diego, J.G., TorresHernández, G., Mahieu, M., Garcia, E.G., and González-Garduno,R.,2007.The epizootiology of ovine gastrointestinal strongyles in the province of Matanzas, Cuba. Small Ruminant Res., 72: 119-126. https://doi.org/10.1016/j. smallrumres.2006.09.002

Ghosh, P.K., Kader, M.A., Riaz, M., and Rahman, M.M., 2016. Retrospective study on parasitic diseases of cattle at Mymensingh district of Bangladesh. Vet. Res. Int., 4: 144-147.

Gwaze, F.R., Chimonyo, M., and Dzama, K., 2009. Prevalence and loads of gastrointestinal parasites of goats in the communal areas of the Eastern Cape Province of South Africa. Small Ruminant Res., 84: 132-134. https://doi. org/10.1016/j.smallrumres.2009.06.013

Hansen,J., and Perry, B.D., 1994. The epidemiology, diagnosis and control of helminth parasites of ruminants. A handbook. Int. Lab. Res. Anim. Dis.,

Hassan, M., Hoque, M., Islam, S., Khan, S., Roy, K., and Banu, Q. 2011. A prevalence of parasites in black bengal goats in Chittagong, Bangladesh. Int. J. Livest. Prod., 2: 40-44.

Hassan, M., Rahman, M., Ali, M., Yousuf, M., Hasan, M., Akther, S., Rahman, M., Islam, M., Hossen, A., and Mondal, M., 2018. A study on prevalence of ecto-and endo-parasitic infection of cattle at Savar, Dhaka. Bangladesh J. Livest. Res., 21-25: 29-35. https://doi.org/10.3329/ bjlr.v0i0.45444

Hossain, M., Amin, M., Mostofa, M., Sharif, M., and Khalid, S., 2004. Efficacy of levanid against natural gastrointestinal nematodiasis and paramphistomiasis in sheep. Bangladesh Vet. J., 21: 70-73.

Islam, M., Rahman, A., Alam, M., and Islam, M., 2020. Gastrointestinal nematodiasis in quail in Bangladesh. Vet. Sci. Res. Rev., 6: 138-142. https://doi.org/10.17582/journal. vsrr/2020.6.2.138.142

Kakar, M., and Kakarsulemankhel, J., 2008. Prevalence of endo (trematodes) and ectoparasites in cows and buffaloes of Quetta,
Pakistan. Pak. Vet. J., 28: 34-36.

Lone, B., Chishti, M., and Fayaz, A., 2011. Prevalence of coccidia and gastrointestinal nematode infections in goats of Barramulla District of Kashmir Valley. Glob. Vet., 7: 27-30.

Pfukenyi, D.M., Willingham, A., Mukaratirwa, S., and Monrad, J., 2007. Epidemiological studies of parasitic gastrointestinal nematodes, cestodes and coccidia infections in cattle in the highveld and lowveld communal grazing areas of Zimbabwe. Onderstepoort J. Vet. Res., 74: 129142. https://doi.org/10.4102/ojvr.v74i2.132

Radostits, O.M., Gay, C.C., Hinchcliff, K.W., and Constable, P.D., 2006. Veterinary medicine E-Book: A textbook of the diseases of cattle, horses, sheep, pigs and goats (Elsevier Health Sciences).

Raza, M.A., Iqbal, Z., Jabbar, A., and Yaseen, M., 2007. Point prevalence of gastrointestinal helminthiasis in ruminants in southern Punjab, Pakistan. J. Helminthol., 81: 323-328. https:// doi.org/10.1017/S0022149X07818554

Raza, M.A., Saeed, M., Bachaya, H.A., Abdul, Q. and Zaman, M.A., 2010. Point prevalence of Toxocara vitulorum in large ruminants slaughtered at Multan abattoir. Pak. Vet. J., 30: 242-244.

Rinaldi, M., Dreesen, L., Hoorens, P.R., Li, R.W., Claerebout, E., Goddeeris, B., Vercruysse, J., Van Den Broek, W., and Geldhof, P., 2011. Infection with the gastrointestinal nematode Ostertagia ostertagi in cattle affects mucus biosynthesis in the abomasum. Vet. Res., 42: 1-11. https://doi.org/10.1186/1297-9716-4261

Roberts, J., Fernando, S., and Sivanathan, S., 1990. Toxocara vitulorum in the milk of buffalo (Bubalus bubalis) cows. Res. Vet. Sci., 49: 289-291. https://doi.org/10.1016/00345288(90)90061-8

Sardar, S., Ehsan, M., Anower, A., Rahman, M., and Islam, M., 2006. Incidence of liver flukes and gastro-intestinal parasites in cattle. Bangladesh J. Vet. Med., 4: 39-42. https://doi.org/10.3329/ bjvm.v4i1.1523

Sharma, D.K., Agrawal, N., Mandal, A., Nigam, P., and Bhushan, S., 2009. Coccidia and gastrointestinal nematode infections in semiintensively managed Jakhrana goats of semi-arid region of India. Trop. Subtrop. Agroecosyst., 11: $135-139$. 
Sharma, S., and Busang, M., 2014. Prevalence of some gastrointestinal parasites of ruminants in southern Botswana. Bots. J. Agric. Appl. Sci., 9: 97-103.

Siddiki, A., Uddin, M., Hasan, M., Hossain, M., Rahman, M., Das, B., Sarker, M., and Hossain, M., 2010. Coproscopic and haematological approaches to determine the prevalence of helminthiasis and protozoan diseases of red chittagong cattle (RCC) breed in Bangladesh. Pak. Vet. J., 30: 1-6.

Soulsby, E.J.L., 1982. Helminths, arthropods and protozoa of domesticated animals (Bailliere Tindall).

Urquhart, G., Armour,J., Duncan, J., Dunn, A., and Jennings, F., 1996. Veterinary parasitology. $2^{\text {nd }}$ edn Blackwell Science Ltd. London, UK 307. 